\title{
Can Governance in Revenue Sharing Be a Pathway for a Win-win Situation between People's Livelihood Improvement and Conservation?
}

Medard Twinamatsiko, Grace Kagoro Rugunda, Benon Basheka \& Tom De Herdt

Social Research Leader and PhD candidate, Institute of Tropical Forest Conservation, Mbarara University of

Science and Technology, P.O Box 44, Kabale; 1410, Mbarara, Uganda

twinamatsikomedard@yahoo.com

Associate Professor, Faculty of Science, Mbarara University of Science and Technology, P.O Box 1410,

Mbarara, Uganda

kgraceug2002@must.ac.ug

Professor and Dean, Faculty of Business and Management, Uganda Technology and Management University, P.O Box 73307, Kampala, Uganda

bbasheka@utamu.ac.ug

Professor and Chair, Institute of Development Policy and Management, University of Antwerp, Antwerpen 2000, Belgium

tom.deherdt@uantwerpen.be

\begin{abstract}
This paper establishes the importance of good governance in improving local livelihoods and support for conservation. The study uses empirical realities from Bwindi Impenetrable National Park, an afromontane Gorilla sanctuary that was recognized by UNESCO in 2005 as a world heritage due to its rich biodiversity. Governance is an important procedural dimension of equity that entails decision making processes and how local people are involved in matters that most affect them. The paper uses a Policy Arrangements Approach to illustrate the procedural dimension of the Justice and Equity Framework. A mixed method approach was used to generate results in this paper. Household surveys, key informant interviews and Focus Group Discussions were employed for data collection. Linear and Multi Logistic Regressions were used to determine the level of significance and relationships that exist between governance, people's livelihoods and conservation support. Polychoric Principal Component Analysis (PCA) was used to generate indices of livelihood improvement and conservation support. Results revealed that meaningful involvement, leadership composition on committees, local capacity, information flow and awareness and accountability significantly influence people's livelihoods and conservation of Bwindi. Local people are not only concerned about distributive equity in benefit sharing but also the procedural dimension. This entails being part of revenue sharing projects from the design phase to the evaluation phase. The study recommends the use of equity framework in revenue sharing in order to increase greater involvement of local people in decision making processes.
\end{abstract}

Key words: Governance, Revenue Sharing Policy, Involvement, Procedural Equity, People's Livelihood, Conservation support, Bwindi

\section{Council for Innovative Research}

Peer Review Research Publishing System

\author{
Journal: Journal of Social Sciences Research
}

Vol. 8, No.1

jssreditor.cir@gmail.com

www.jssronline.com 


\subsection{INTRODUCTION}

Governance as a procedural dimension of equity is fundamental in achieving conservation support through improved livelihoods of local people. This process entails proper practices of good governance principles (Koh, 2009). These principles are used in this paper as parameters to understand the governance aspect of Revenue Sharing policy implementation at Bwindi. These are; attendance of and participation in meetings, involvement in revenue sharing activities, decision making outcomes, equity, accountability and transparency, information flow and awareness, leadership on committees and capacity to influence decisions as key indicators of governance at Bwindi. Only significant indicators after regressions have been discussed in this paper.

Globally, the phenomenon of good governance in conservation is attracting debates as to whether conservation policy interventions can best adopt it as a pathway for improved human livelihoods (Wells et al., 1993; Hughes \& Flintan, 2001; Simpson, 2008:3; Blomley et al., 2010; Salafsky, 2011:975; Twinamatsiko \& Muchunguzi, 2012; Twinamatsiko et al., 2014). The implementation of revenue sharing policy is premised not only on benefit distribution but also on good governance. If well implemented using an equitable framework, it can be a facilitator of improving people's livelihood and influence their support for conservation of Protected Areas. There is often contestation between local communities and protected areas premised on inadequate benefits and limited involvement to address their livelihood needs yet such communities bear conservation costs. Revenue sharing objectives are premised on improving people's livelihoods in order to gain their support for conservation. This process entails decision making processes where local people are supposed to identify and prioritize projects that greatly influence their livelihood in order to make a trade-off for conservation to take place. Empirical realities however show that the practice of Integrated Conservation and Development (ICD) policies around Bwindi does not address the initial objectives of the policy which has resulted into negative attitudes towards conservation (Twinamatsiko et al., 2014). This justifies this research that understands the importance of revenue sharing policy governance to address community livelihoods and facilitate support for conservation. The preliminary findings analysed by the researcher before embarking on this study (Blomley et al., 2010; Twinamatsiko et al., 2014), demonstrated that community livelihoods around Bwindi lacked a linkage to the governance dimension of equity.

In pre-colonial era, communities were socially organized in various ways from kingdoms to chiefdoms and clan systems. This organisation was so evident in Asia, Latin America especially in Indonesia and countries in Africa such as Cameroon, South Africa, Uganda and Kenya. In Uganda, the most significant kingdoms were those of Bunyoro, Buganda, Toro, and Busoga. Forests were owned by kingdoms and each kingdom managed the forests either as a communally owned or an open access resource (Baker et al., 2013). Due to the traditional norms and beliefs, some forests were classified as sacred, in which case an individual or clan was assigned the responsibility of regulating use of its resources. This would entail sanctions put in place for the misuse of forest resources that were learnt by societies through stories and folklore. For example, one of the beliefs by Ugandan societies was that, if one went into the forest without reporting the purpose of the visit to the spiritual leader or clan head, that individual would not be able to find his or her way out and back to their village (FFI, 2013). This level of organisations of clans, cheifdoms and kingdoms helped in managing and governing resources for livelihood improvement of local people and their ability to conserve natural resources. This institutional approach entailed making people part of the implementation process but not excluding them. Evidence shows that wildlife populations were not as high on community land as in the current protected areas but were held in check by humans through hunting (DeGeorges and Reilly, 2009).

It has been noted that, forest conservation as a regime of governmentality began during the colonial era and was intertwined with the colonial notion of private property and startial governmentality (Pemunta \& Mbu-Arrey, 2013). In Cameroon for example, state intervention was based on the assumption that primary forests were not in use and were seen primarily as forests (Abbot et al., 2001) in which local people have never exercised any rights (Aubreville, 1949:100). Following the declaration of Uganda as a British protectorate in 1890, the colonial administration promulgated different policies to overhaul the traditional systems of administration. This was also experienced in Indonesia, Cameroon, Kenya and many African countries. This new paradigm saw the deportation of traditional rulers of who most were either imprisoned or exiled due to resistance. Those who collaborated with colonialists adopted the new systems of administration. The administration of colonialists did not involve the true understanding of governance. One of the first acts of the colonial administration was to control natural resource use (Baker et al., 2013).

The colonial authorities recognized the systems of land ownership and resource management under the kingdoms although local people were excluded from decision making processes. In areas without kingdoms, there were hierarchical resource management systems based on clans and chiefs (Baker et al., 2013). The British colonial masters abolished these traditional systems of governance and management and imposed new management regimes to govern natural resource use. This included the designation of large areas as crown property where local people were forbidden to enter and collect resources. Decisions were too centralised with limited involvement of people at lower levels. At this time estates were established for crops such as coffee, tea and sugar cane that resulted in large scale clearance of Uganda's forests. The colonial administration however realized the need to manage forests, particularly for timber production, and began management of Uganda's forest estate towards the end of the 19th Century (Turyahabwe and Banana, 2008). It is therefore important to note that, protection of areas herein this paper referred to as conservation of forest reserves is a child of colonial policies (Twinamatsiko and Muchunguzi, 2012; Pemunta and Mbu-Arrey, 2013).

Making communities part of the governance regime and sharing with them conservation revenues is also not a new discourse but can be traced as far back as 1940s in the colonial era in various nations in the world (Newmark and Hough, 2000). As early as 1940's there was increasing recognition that conservation provided revenue generating opportunities that would contribute to local economic development in poor communities (Roe and Elliott, 2010 while quoting Adam, 2004). Community Based Approach to conservation was a response to the protectionist approach and the latter's failure to address the trend of illegal activities and sustainable resource use. From a conservation perspective, natural resource areas are paramount for conservation. This can not only be achieved using a protectionist approach with guns. Batisse (1986:69) notes that over the two decades before 1980, boundaries of natural areas in the world especially developing 
countries began to be affected and there was a lot of biodiversity loss. In response to this challenge, UNESCO's man and Biosphere programme of Biosphere reserves proposed that protected areas be safeguarded using several approaches such as buffering, community decision based approaches and the historical law enforcement (Batisse, 1986; Butynski, 1984).

The formalization of a Community Based Approach (CBA) to conservation hereafter referred to as Integrated Conservation and Development (ICD) which houses revenue sharing policy is a recent paradigm of 1980s. Integrated Conservation and Development (ICD) as a community based approach officially began in 1982 as a conventional approach to conservation following the $3^{\text {rd }}$ World Parks Congress. It recognised the importance of local participation, sharing benefits with people neighbouring protected areas, sustainable resource use and collaborative park management. The policy began in Latin America in countries such as Indonesia and some African countries such as South Africa, Zimbabwe, Zambia and Tanzania (Roe and Elliott, 2010). In Indonesia, the first ICD was launched in 1982 much as similar ideas of sharing revenue with communities had been informally implemented since 1950s (Wells et al., 1993). A review of ICDP performance in Indonesia concluded: '...very few ICDPs in Indonesia can realistically claim that biodiversity conservation has been or is likely to be significantly enhanced as a result of current or planned activities ..." (Wells et al., 1993:17).

The issue of how to deliver benefits from Protected Areas to local people using a bottom-up approach where decisions come from the people has long been recognized as of great importance. The fifth objective of Bali Action Plan, which was a product of the 3rd World Parks Congress in 1982 aimed at promoting the linkage between protected area management and sustainable development (McNeely \& Miller, 1984). Under their recommendation 5 of the $3^{\text {rd }}$ World Parks Congress, in order to gain people's support for conservation, it was realized that people needed to share appropriately in the benefits flowing from Protected Areas, be compensated appropriately for any lost rights and be taken into account in planning and operations (Baker et al., 2013; Twinamatsiko et al., 2014). In 1985, WWF recognized the need to tackle poverty and local economic development around Protected Areas seriously (Roe and Elliott, 2010:4).

Ten years following the 3rd World Park Congress, in 1993 at Caracas declaration, participants also agreed that the management of protected areas must be carried out in a manner sensitive to the needs and decision making by the local people (Scherl et al., 2004 while quoting McNeely, 1993). After ten years during the fifth IUCN World Parks Congress held in Durban-South Africa, participants resolved to find innovative and effective ways to position protected areas within sustainable development and poverty reduction strategies (Baker et al., 2013). This was after analyzing a list documented by United Nations (UN) showing the extent the earth surface was covered by terrestrial Protected Areas of about 17.1 million $\mathrm{km}^{2}$ and moreover most found in developing countries (UN, 2003).

Uganda in the post-colonial era has however continued to implement conservation policies that exclude local communities as an approach to managing PAs in Africa (Agrawal \& Gibson, 1999, Twinamatsiko et al., 2014). This is witnessed with the top bottom approach that is mostly used in implementing conservation policies. Local communities that used to have full access to wildlife resources were excluded from the established protected area management. This exclusion has surfaced through deployment of military trained rangers, whose job has been to enforce wildlife laws by apprehending lawbreakers and either levying a fine on them or handing them over to courts of judicature for prosecution (Baker et al., 2013). This arrangement builds on the already existing conflicts of dispossession at the time of gazettment. Local community members, in efforts to secure their means of survival, were the majority of culprits of this wildlife management set up, and it caused much tension and conflicts between PA managers and the local people (Mugisha, 2002).

At the $9^{\text {th }}$ Conference of Parties in 2008 under decision IX/18, parties were encouraged 'to ensure that conservation and development activities in the context of protected areas contribute to the eradication of poverty and sustainable development' (Baker et al., 2013:6). The 2011-2020 Strategic Plan for CBD under decision X31 established an agenda for biodiversity conservation to contribute towards poverty eradication and the $10^{\text {th }}$ Conference of Parties encouraged parties to 'support initiatives on the role of protected areas in poverty alleviation' (Twinamatsiko et al., 2014).

In Uganda, a revenue sharing policy for PAs began at Bwindi in 1994 as a pilot study for other Protected Areas. Under this policy arrangement, the then Uganda National Parks (UNP) which was a parastatal managing Uganda's national parks was required to give 12 per cent of their total gate revenue collections from tourists to the local communities (Tumusiime and Vedeld, 2012:15-16). In 1995, the UNP formally adopted revenue sharing as a wildlife management policy, and in 1996, it was recognized under legislation - the Uganda Wildlife Statute (now the Wildlife Act, Cap 200 of the Laws of Uganda, 2000). The Act also merged Uganda National Parks and the Game Department into the Uganda Wildlife Authority (UWA) in 1996 (Baker et al., 2013:10).

The Government of Uganda passed revenue sharing legislation under the Uganda Wildlife Law (2000). Under this act, UWA is obliged to share $20 \%$ of its gate collection revenue and part of gorilla levy fees from its protected areas with the neighboring communities (UWA, 2000a). According to the act, adjacent parishes which are referred to as frontier communities are supposed to benefit from revenue sharing. The interpretation of the word 'frontline community' has remained vague for proper policy practice. Revenue sharing is not only practiced in Uganda. Other countries such as Indonesia, South Africa, Rwanda and Tanzania implement a benefit sharing programme. The implementation modalties however differ although challenges seem to be the same. For instance, generating local benefits directly from ICDPsupported protected areas (PA) has not proved easy in Indonesia. Tourism revenues have not so far lived up to expectations, although they could become significant for a few PAs on Java and the marine PAs with attractive coral reefs. Entry fees are very low (less than \$1), with $70 \%$ passing to local government and $30 \%$ to central government (Hughes \& Flintan, 2001).

The goal of revenue sharing is to ensure that the people living adjacent to protected areas (PAs) obtain benefits from the existence of these areas in order to gain their support for conservation. This is to be achieved through an approach where people identify projects that address their needs and priorities. Furthermore, the intentions and purpose of Section 70 (4) of the Uganda Wildlife Statute (1996) is to enhance communities' benefits from PAs as partners in management and conservation of PA resources (UWA, 1996; UWA, 2000a). The Government of Uganda has since then encouraged 
partnership between UWA, local communities and local governments leading to the sustainable management of resources in and around PAs. This has been achieved mostly through local informal groups that work as conduits for collaborative management. The only formal group was the Community Protected Area institution (CPI) which was disbanded in 2012 (UWA, 2012b).

This paper therefore addresses the following key questions in order to ascertain the importance of governance in improving people's livelihoods and their support for conservation; How do local people define good governance of revenue sharing projects?; How are the revenue sharing guidelines practiced in the context of good governance principles?; What is the influence of governance of revenue sharing projects on livelihood improvement of people boardering Bwindi? and does governance of revenue sharing projects influence people's support for the conservation of Bwindi?

\subsection{THEORETICAL AND CONCEPTUAL DEVELOPMENT}

This study uses the Policy Arrangements Approach (PAA) to explain the linkage between governance of revenue sharing policy, people's livelihoods and conservation of Bwindi Impenetrable National Park. PAA has been accepted by scholars as one of the policy and institutional approaches that can explain contemporary policy processes in the field of environment and nature related studies. The approach was advanced by Van Tatenhove (1999) and further expanded by Art et al. (2006) to give analytical overview on the study of policy processes (Ahebwa et al., 2012). This paper applies PAA to better explain the implementation process of revenue sharing policy in the context of community livelihoods and their support for conservation. PAA links daily policy processes and structural processes of social and political change. This is relevant since Revenue Sharing policy operates in a structural arrangement in line with the Act of Parliament of 1996 and the Local Government act of 1997. The arrangement of sharing revenue is made in a way that corresponds with the government structures in Uganda. The daily policy processes entail the actual implementation of the policy on ground which includes local actors (leaders and beneficiaries) in interpreting the structural arrangement, its applicability and social norms that explain its limitations.

PAA presents key assumptions which are relevant to this study. The approach is premised on; actors and coalitions; power, resources and influence; rules of the game and policy discourses. Van Tatenhove et al. (2006) identifies actors as organizations or individuals involved in nature policies concerning a specific nature site. Coalitions are looked at as groups of cooperating actors who share rules of the game and implement and forecast joint policy discourses through their programmes (Van Zouwen, 2006:20; Arts et al., 2006:63). For this case in revenue sharing policy implementation, there is an interplay of various actors involved. These actors include; the central Government of Uganda (GoU), Uganda Wildlife Authority (UWA), Local Governments (LGs) which entail both Higher Local Governments and Lower Local Governments, Conservation Organisations and Institutions outside the realm of Government control and community beneficiaries. It is noted by Arts (1998: 57-59) that policy arrangement is a system of power which is linked to influence. Power mainly concerns the ability to influence policy outcomes through actions and interventions. The deficit in the implementation of most of Integrated Conservation and Development programmes has been the power vacuum at grass root level (Twinamatsiko et al., 2014; Blomley et al., 2010). At Bwindi, power is much centralized (Namara, 2006) and this limits the ability of local people to influence actions that have to be undertaken by policy makers. There are also marginalized groups especially the Batwa who have very limited capacity to challenge other actors on key issues that affect the implementation and governance processes.

The approach also assumes that, there should be rules in the game of policy implementation. Arts and VanTatenhove (2000:54) while expanding on the arguments of PAA, clarifies that a policy arrangement should be a temporary stabilization of the organization and substance of a policy domain which should be guided by rules at a specific policy level of policy making. Arts however, fails to link his arguments to policy implementation where rules are either broken or replaced by personal or social norms and constructs that fit certain individuals and institutions. It is important to note that, in implementing policies, new ideas and rules emerge hence affecting the set rules and principles that guide the implementation process. The rules of the game therefore determine opportunities and barriers for the actors to act during a policy process. Rules can be formal or informal. At Bwindi, revenue sharing policy is implemented under guidelines that were reviewed in 2012 (UWA, 2012a). There are however informal community guidelines that the implementers fail to recognize yet are paramount for the policy success. The last assumption of this framework is policy discourses. Arts and Van Tatenhove (2000:63) refer to policy discourses as key interpretative schemes ranging from formal policy concepts to popular story lines. This to him makes meaning to a given policy domain. Actors at Bwindi have continued to formulate actions and discourses that further guide the implementation process of revenue sharing without involving local people in the project design. Community meetings take place but with limited or no involvement by local people. This is terms of meeting outcomes but also action frameworks agreed upon and what is actually done.

The Policy Arrangements Approach creates a basis for the adoption of the theory of access by Ribot and Peluso (2003) and the Justice and Equity Framework (Schlosberg, 2007). The theory of access creates an analysis of who actually benefits from resources and through what processes they are able to do so (Ribot and Peluso, 2003). The equitable framework describes the use of four dimensions of procedures, distribution, recognition and context of benefiting. The theory of access links benefits of natural resources to the process through which people benefit. It understands the aspects of property rights and rules that govern access to natural resources. The theory also illustrates the likely limitations and opportunities that would affect the ability to benefit. The linkage between property rights, access and benefits has been explored under this theory. The theory further illustrates the access mechanisms and the framework of change. Focusing on natural resources, the theory analyses the range of powers embodied in and exercised through various mechanisms, processes, and social relations that affect people's ability to benefit from resources. The powers identified here could be material, cultural and political-economic strands that determine resource access.

Ribot and Peluso (2003:155) note that people and institutions are positioned differently in relation to resources at various historical moments and geographical scales. The strands thus shift and change over time, changing the nature of power and forms of access to resources. Over all access is linked to all possible means by which a person is able to benefit from 
the natural resources. This theory fails to explain people's ability to influence decisions that aim at livelihood improvement. It also does not justify whether access to benefits and resources enhance community ability to support conservation efforts. Therefore the conceptual framework of this paper (Figure 1) originates from the theory access and Justice and Equity Framework based on the Policy Arrangements Approach.

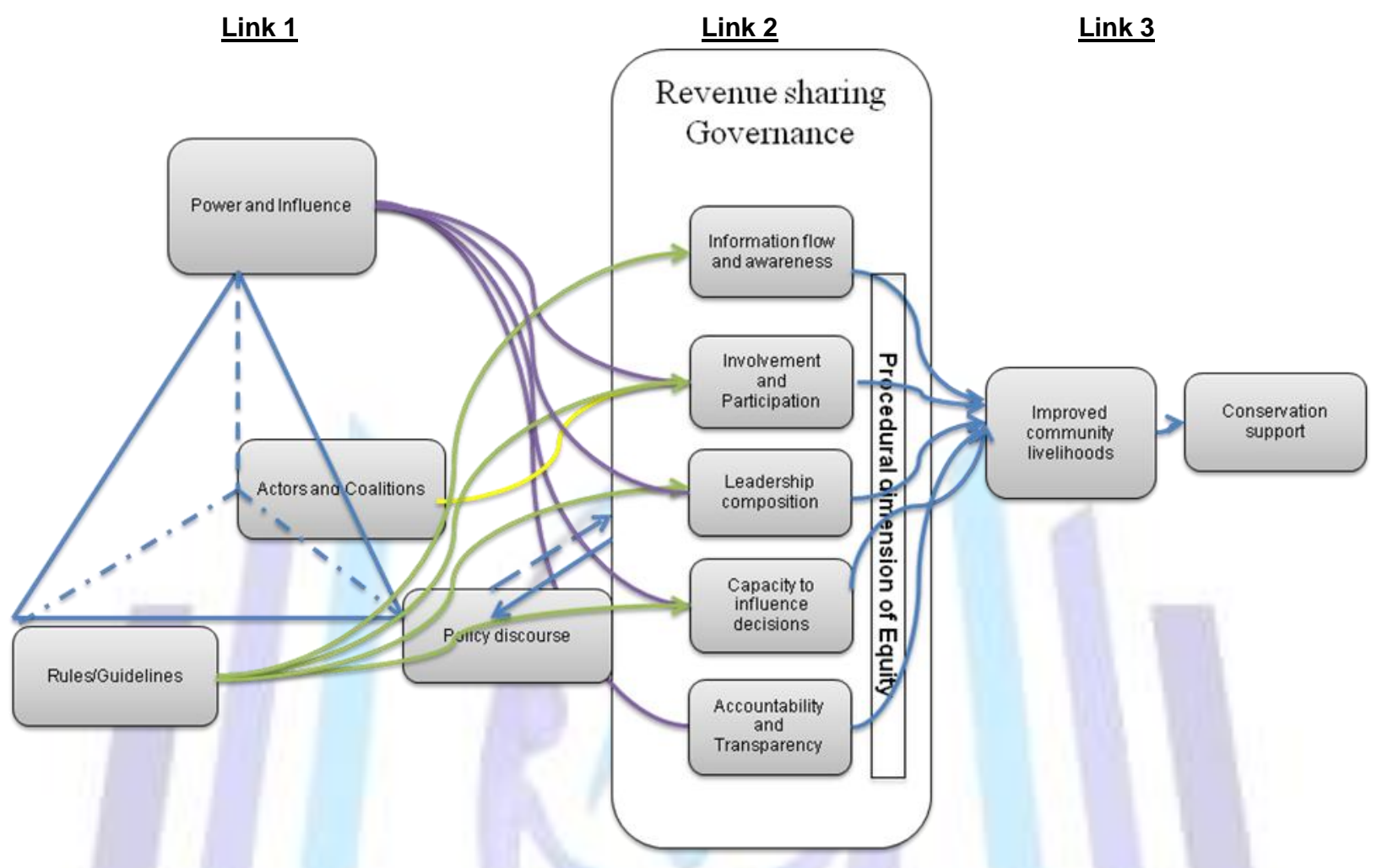

Figure 1: Use of Policy Arrangements Approach to explain the Theory of Access and Justice Framework as yardsticks for governance

From the theoretical underpinnings, this paper observes that, linking conservation with livelihood improvement is more than effective national park management but requires that the issues of governance, human rights, equity and power are addressed at highest levels (Baker et al., 2013). Participation as one key form of governance is fundamental for revenue sharing and other ICDs yet it has been documented that most projects failed to devolve natural resource management to local people in the early days of ICD interventions (Ghimire, 1994). Participation of a community in the planning and operational aspects of an initiative or within ownership structures is not an aspect to under look if benefits are to be conveyed (Simpson, 2008: 3). An earlier internal review done by WWF found out that the key interests of important stakeholders and their participation had not been incorporated in natural resource management yet local resource use was intensive (Larson et al., 1997). Governance is a key form that would influence people's attitude to conservation since they would take part in issues that affect their livelihood. This involves inclusiveness in decision making processes which at the end makes any possible interventions owned by the local people. This paper has established that the missing gap between governance and livelihood improvement has been a major factor explaining negative attitudes and illegal practices on natural resource use.

The bivariate results by Brook et al. (2013) suggest that project design is important for success. Participation, engagement, project benefits, and human/social capital were particularly crucial, as variables from these clusters were significantly associated with each of the four outcomes. While participation of local communities in national park management has increased, the type of participation is rarely defined, which limits understanding of whether genuine participation has been achieved where communities felt engaged with the decision-making process, and how effective this was in securing both livelihood improvement and conservation goals (Namara, 2006). The process by which power and responsibilities are exercised and decision undertaken can have a significant influence on the conservation of protected areas. The last section of this paper brings some suggestions to these gaps. Achieving good governance within the context of revenue sharing initiatives includes the regular and inclusive participation of informed local communities in decision-making, fair compensation for the costs of conservation and equitable benefit sharing that addresses the needs of the poor and marginalized. Involvement of local people in project design is key for project success.

From the current studies, the governance principles have been practiced at Bwindi in natural resource management (Bitariho, 2013; Namara, 2006). UWA policies and plans streamline how communities neighbouring Bwindi should share part of the revenue that comes from park revenue. Groups have been formed to facilitate the process of benefit sharing. This is manifested through various groups such as Resource Use Committees and the former Community Protected Institution. There are other informal park related groups operating around Bwindi that include HUGO committees and 
reformed poachers committees. Community Protected area Institution (CPI) was established as a formal community link to national park management in enhancing collaborative forest management. $\mathrm{CPI}$ involvement in collaborative management was however analyzed to be inadequate and difficult to understand (CARE, 2006). There are also various informal and formal community groups around Bwindi. These groups channel local interests to UWA with the aim to increase community involvement in natural resource management. The level of success in achieving the collaborative forest management and governance remains an area of concern if a win-win situation is to be reached at in governing BINP resources.

As recently noted, key factors to balance the tradeoffs of successful programmes lies in the creation of inclusive, adaptive, and sustainable governance structures that build partnerships, empower people, foster dialogue, and emphasize the use of the best science available (Koh, 2009; Scherl et al., 2004). This is true given the fact that people ought to be put at the centre of project processes if they are to succeed. A focus on governance of protected areas helps in understanding the interactions among structures, processes and traditions that determine how power and responsibilities are exercised and how decisions are taken and how citizens and all stakeholders see the management of natural resources. Good governance and the involvement of local governments and communities in natural resource management are prominently featured in current debates on sustainable management of natural resources (Koh, 2009).

\subsection{SITE, METHODS AND MATERIALS}

\subsection{Site Description, Research Context and Design}

The study was conducted around Bwindi Impenetrable National Park (BINP). BINP is located in the Albertine Rift- South Western Uganda and covers three districts of Kabale, Kanungu and Kisoro. The park is bordered by 27 densely populated parishes that are highly marred by poverty levels. This study covered 19 parishes. The Park is a world heritage and home for world endangered species both fauna and flora (UNESCO, 2005; McNeilage et al., 2006). Bwindi was gazzetted in 1932 as the Kasatoro and Kayonza Crown Forests (UWA, 2001). In 1942, the two Crown Forests were unified as Bwindi Central Crown Forest, which, in 1961, was gazetted as a gorilla sanctuary and in 1991 the area was gazetted as a National Park (Tumusiime and Svarstad, 2011).

This study used a mixed method research design after a review of various literature sources by authors who discussed various limitations and strength of other research designs. Creswell (2009: 203) recommends use of mixed methods research design in order to broaden understanding of the discipline by incorporating both quantitative and qualitative research approaches or to use one approach to better understand, explain or build on the results from the other approach (Creswell, 2009:204-205). In the mixed method design, cross sectional and case study designs were used for quantitative and qualitative approaches respectively (Creswell, 1998; Neuman, 2011; Creswell, 2011).

\subsection{Target Population and Sampling}

This study employed a cross section of people around Bwindi population in order to substantiate and correlate various views on revenue sharing policy governance. The study used 565 local community members as primary respondents, 30 key informants (10 staff of Uganda Wildlife Authority, 01 senior staff of Bwindi Mgahinga Conservation Trust, 01 senior staff of International Gorilla, 3 planners of District Local Governments, 10 Local Government elected leaders and 05 opinion leaders around Bwindi including old staff from ITFC and elders in the community). 120 selected local leaders, former CPIs and local opinion leaders participated in 10 Focus Group Discussions (FGDs) to understand the local perceptions and what communities thought as local solutions to the proper implementation and governance of revenue sharing policy. This whole sampling approach generated a total sample of 715 participants who were representative enough of the entire population (Creswell, 2009). Large samples are also recommended in historical studies as representative to the entire population and build confidence in the conclusions (Krig, 1952; Neuman, 2011). Sampling was done using stratified sampling, simple random and purposive sampling. Stratified sampling was used to generate strata for the districts, Batwa and non Batwa, men and women. Stratified sampling technique was adopted to categorise Batwa and non-Batwa households. Neyman (1934:558) recommends the use of stratified sampling in order to segregate differences within the sample population.

\subsection{Data Collection Methods and Data Quality Control}

The use of various data collection methods allows methodological triangulation during various phases of the research (Patton, 2002). Primary methods included; Household surveys, Key Informant Interviews, Focus Group Discussions (FGDs) and observation. Secondary data method included documentary reviews in journals, book chapters, field reports and UWA records.

Validity and Reliability of the study were ensured to achieve some high degree of accuracy and consistence of the data collected. This was achieved through conducting a pilot test of the instruments that were used in data collection. The household survey questions were pre-tested and sorted during data collection process. Creswell (2009:27) suggest that validity in qualitative research estimates whether the researcher sees what he or she thinks so that there is evidence in the data for the way in which data are interpreted. Validity of research instruments were measured using content validity (Polit and Beck, 2004). The researcher went ahead to calculate a Content Validity Index (CVI). The CVI range for this study was 0.7 and this justified the accuracy of the results for each of the values on the scale (I-CVI) and the overall values (S-CVI). The use of NVivo computer package in coding and managing data further enhanced validity of data. Reliability of the instrument on the variables was tested using the Cronbach alpha method and a Cronbach alpha $(\alpha)$ of 0.7 made the instrument to be taken reasonably reliable. Reliability of research questionnaire was measured using test and retest technique. 


\subsection{Data Analysis and Measurement}

All generated data from the field was cleaned, coded and entered into Microsoft access 7. Quantitative data collected from household surveys was analyzed using STATA 11 statistical package where summarized field data on numerical variables was entered into the computer and after, tables and figures were generated to use in the presentation of data for easy interpretation. Statistical tests were undertaken using parametric and non-parametric tests according to the way the data were distributed. Multinomial Logistic Regression (MLR) and Linear Regression (LR) formed most part of the analysis of the various processes of revenue sharing implementation and livelihood improvement of people around Bwindi. This study further used Polychoric Principal Component Analysis (PCA) to generate indices for indicators of livelihood improvement and conservation support (Kolenikov and Angeles, 2004). Qualitative data was analyzed using thematic content analysis. This was aided by NVivo computer package. NVivo has proven as a powerful tool that can manage qualitative data (Silver and Lewins, 2014).

$P$-value was used to test the study hypotheses and determine the level of significance between revenue sharing policy implementation, livelihood improvement and conservation support. For non-significant results, exact values are given for $P$-values $<$ or $>0.05$, and $P$ values $>0.1$ were reported as $>0.05$. For significance results, $P$-values are reported as $<$ 0.05 (Sandbrook, 2006; Dytham,1999). For correlations (Linear and Multinomial Logistic Regressions), the study employed the formula of given below to determine the value of the relationships;

$$
r=\frac{n \sum x y-\left(\sum x\right)\left(\sum y\right)}{\sqrt{n\left(\sum x^{2}\right)-\left(\sum x\right)^{2}} \sqrt{n\left(\sum y^{2}\right)-\left(\sum y\right)^{2}}}
$$

The formula for polychoric PCA was given as;

$$
\text { Index } \left.=\sum_{k=1}^{K} w k \cdot X k+\underset{\substack{D \\
d=1}}{D}, \ldots w d, z\right]\left[\begin{array}{l}
X d, 1 \\
\ldots \\
X d, z
\end{array}\right]
$$

\subsection{RESULTS}

\subsection{Community definition of good governance of Revenue Sharing}

During household surveys and FGDs, community members defined good governance as a process of putting community members at the centre of decision making processes right from revenue sharing project selection up to the final stage of project evaluation. Communities prefer a bottom-up approach and greater involvement. Local leaders further indicated that the current arrangement at Bwindi Impenetrable National Park does not full involve local people in protected area governance.

$70 \%$ of the 10 FGDs reported that in all processes of revenue sharing implementation and governance, decision making that is collaborative was paramount to generate viable successes of the policy. This approach was also coined during the Focus Group Discussion of comprehensive CTPA study where collaborative decision making and implementation in ICD was the approach preferred by local communities regarding governance of the policy (Twinamatsiko et al., 2014). Discussions on this approach highlighted the importance that local communities placed on collaborating with other stakeholders in both the decision-making and implementation stages of revenue sharing projects. Two FGDs (20\%) reported consultative approach in decision making, implementation and monitoring processes whereas the remaining one FGD mentioned participatory decision-making and implementation of revenue sharing policy. All FGDs agreed that community members ought to be part of the implementation processes and should be involved in the governance of revenue sharing projects.

When UWA management was consulted during key informant interviews to give a view on community understanding of governance, it was reported by the CCW that UWA tries as much as it can to collaborate with local communities. In some cases however, local community members shun implementation activities such as meetings and follow up of revenue sharing funded projects. One incidence was cited in Mpungu and Ruhija Sub Counties where the tenderer connived with local residents and instead of receiving goats; they received money not worth the budget.

Box 1: Community's role in good governance
Local people are funny when it comes to practice good governance..In Ruhija and
Mpungu, we had budgeted a goat at 120,000 UGX but the tenderer and his team
connived with local people and instead gave them cash 50,000 UGX. When we
called upon the community to testify, they failed to pin him yet they knew...
(Community Conservation Warden, Bwindi Impenetrable National Park, March
2014)

\subsection{The practice of Revenue Sharing Guidelines}

The study findings revealed that there are existing revenue sharing guidelines which are supposed to be followed by all stakeholders while implementing revenue sharing policy. The new guidelines are a revision of the old ones that were reviewed between 2010 and 2011 and became official in 2012. Uganda Wildlife Authority Conservation Area manager of Bwindi Mgahinga Conservation Area (BMCA) reported that, the revised revenue sharing guidelines of 2012 clearly 
stipulate the implementation and governance of the disbursed funds to benefiting communities. The entry point is the District Local Government, Sub County and then procurement committees that later trickle down to beneficiaries. Local people are supposed to be put at the centre of the implementation. This should be done through meetings in frontline villages. Local people are supposed to be part of the governance structures such as Project Management Committees (PMCs) and Community Procurement Committees (CPCs). The institutional design is decentralized in decision making processes and the policy uses a bottom up approach. This is because, communities identify projects that meet their needs and priorities and proposals are done by the PMCs and submitted to the Parish Development Committee for prioritisation. The Community Conservation Warden further revealed that the current guidelines would be adequate enough to enable address of livelihood insecurity but the challenge remains with the implementers. She reported that UWA guidelines follow the annual Local Government planning cycle.

This research through an in-depth documentary analysis of the new guidelines however identified various contradictions in the governance modalities and general implementation process. To begin with, the prioritisation of the projects where frontline communities should be at the centre of decision making processes is done at the Parish and Sub County levels through the Development Committees yet the guidelines show that local people in the frontline communities will meet and select projects based on their needs and priorities (Section 8.4, UWA, 2012a:15-16). This study further established the hierarchy in implementing revenue sharing policy. The process of implementation is looked at by community members as a challenge and limitation to their involvement and benefit. The chain of command illustrated in Figure 2 shows a flow of revenue sharing money from the Protected Area management to the beneficiaries. Most community members and lower local leaders revealed dissatisfaction about this hierarchy to benefit and its limitations to integrate everybody in decision making processes.

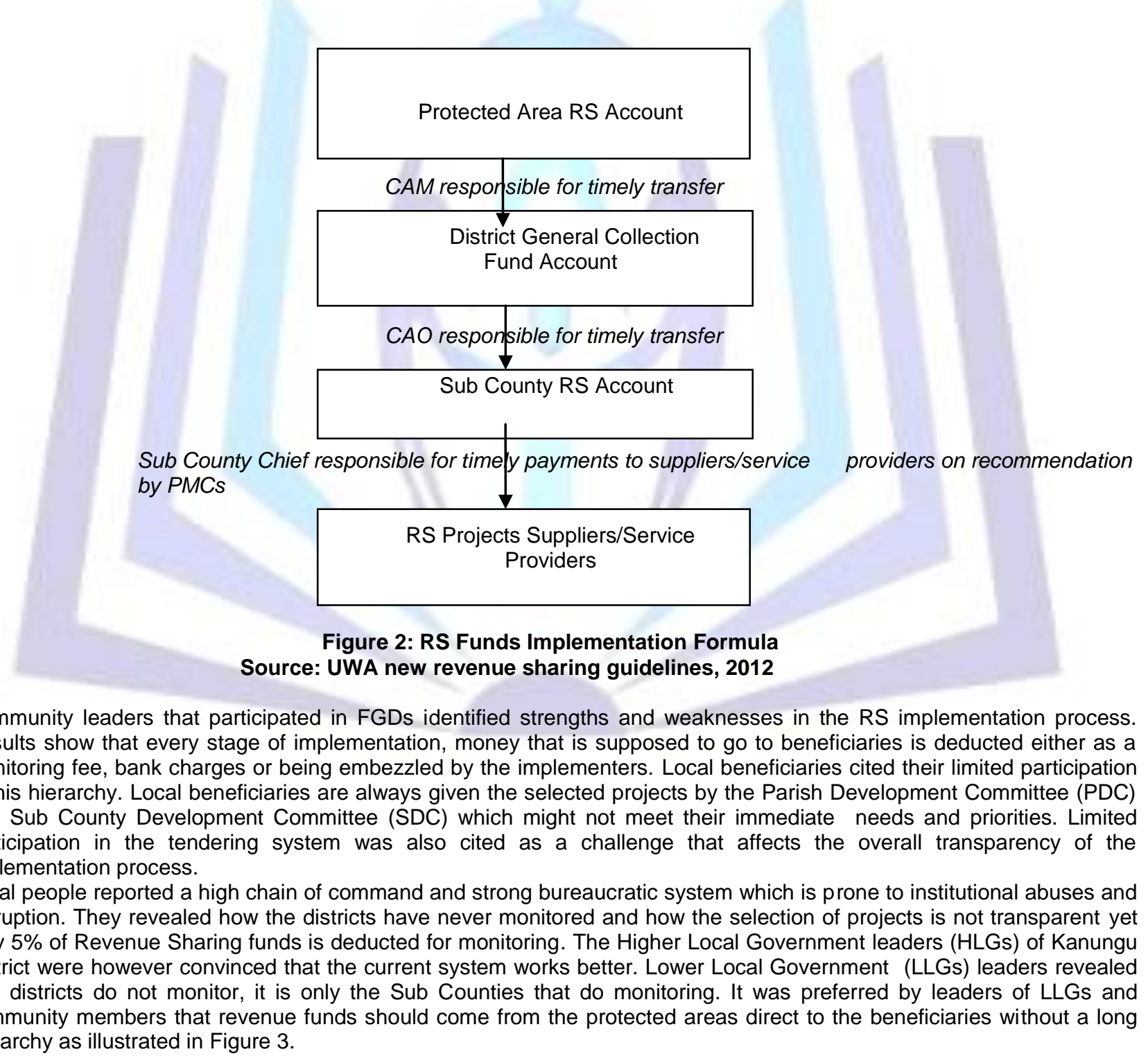




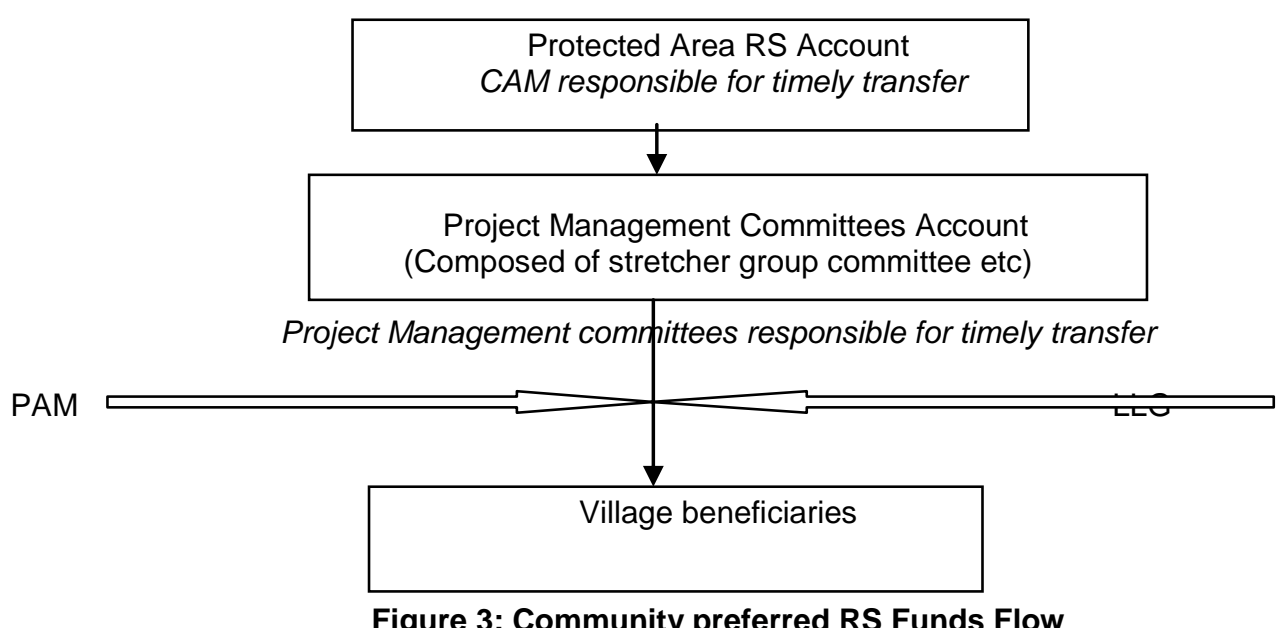

Figure 3: Community preferred RS Funds Flow Source: FGDs, February 2013

As illustrated in Figure 3 above, local people revealed a need for direct funding of community beneficiaries if UWA revenue sharing program is to succeed and improve the livelihoods of communities surrounding protected areas. This would reduce cases of funds' loss as a result of institutional bureaucracy and corruption practices.

\subsection{The influence of Governance on People's Livelihood Improvement}

Indicators of good governance were used to understand their relationship with livelihood improvement. This was intended to determine whether governance is a key factor to influence livelihoods of people bordering Bwindi Impenetrable National Park. After linear regression, not all indicators were significant $(P$-value $\leq 0.05)$. Only significant indicators are presented in this section of the paper to test the study hypothesis that governance of revenue sharing projects influences livelihood improvement and to also determine the level of significance. These indicators include; involvement, information flow, leadership engagement on committees and capacity to influence decisions. The table below presents the values for each indicator.

Table 1: Relationship between Governance and livelihood improvement

\begin{tabular}{|c|c|c|c|c|}
\hline Parameters & Coefficient & Pvalue & $\mathbf{t}$ & $\begin{array}{l}\text { Standard } \\
\text { error }\end{array}$ \\
\hline Involvement & $0.11^{*}$ & 0.02 & 2.28 & 0.05 \\
\hline Information flow & $-0.17^{*}$ & 0.01 & -2.43 & 0.07 \\
\hline $\begin{array}{l}\text { Leadership on committee } \\
\text { composition }\end{array}$ & $-0.05^{\star *}$ & 0.011 & -2.57 & 0.02 \\
\hline Capacity to influence decisions & $-0.35^{\star \star *}$ & 0.000 & -4.66 & 0.07 \\
\hline
\end{tabular}

*** Very highly significant at $5 \%$

** Highly significant at 5\%

* Significant at $5 \%$

\subsubsection{Involvement and Participation}

Table 2 indicates that most of the beneficiaries $173(40.8 \%)$ of revenue sharing projects were not involved in the implementation of revenue sharing policy compared to $136(32.1 \%)$ who were involved a lot. Another substantive percentage $(27.1 \%)$ felt little or some involvement during implementation and benefit.

Table 2: Ranking of Revenue Sharing Projects in terms of involvement

\begin{tabular}{lrrrrr}
\hline \multirow{2}{*}{ RS Projects } & \multicolumn{5}{c}{ Level of Involvement } \\
\cline { 2 - 6 } & None & Little & Some & A lot & Total \\
Livestock & 59 & 22 & 27 & 56 & 164 \\
Trees/Seedlings & 20 & 3 & 1 & 4 & 28 \\
\hline
\end{tabular}




\begin{tabular}{lrrrrr}
\hline Schools & 13 & 1 & 8 & 25 & 47 \\
Health centres & 17 & 2 & 6 & 9 & 34 \\
Crop raiding control & 23 & 7 & 16 & 18 & 64 \\
Roads & 9 & 2 & 5 & 7 & 23 \\
Land provision & 14 & 1 & 1 & 4 & 20 \\
Water & 13 & 1 & 7 & 7 & 28 \\
Other livelihood projects & 3 & 2 & 0 & 1 & 6 \\
Other general projects & 2 & 2 & 1 & 5 & 10 \\
& & & & & \\
Total & $173(40.8 \%)$ & $43(10.1 \%)$ & $72(17 \%)$ & $136(32.1 \%)$ & $424(100 \%)$ \\
\hline
\end{tabular}

Findings indicate that Bwindi uses a top bottom approach in the selection of projects and announces decisions that have already been undertaken. Participatory decision making and implementation happens but at a low rate since projects are always decided by those that can influence the group and Parish Development Committees (PDCs).

The study evaluated the governance of revenue sharing by analyzing whether all local people (both men and women) have been involved and the capacity they have to influence decisions. Results reveal gender inequalities in both decision maiking processes and committee compositions. Figure 4 and 5 indicate that there are few women on the Project Management Committees (PMCs) and Community Procurement Committees (CPCs).

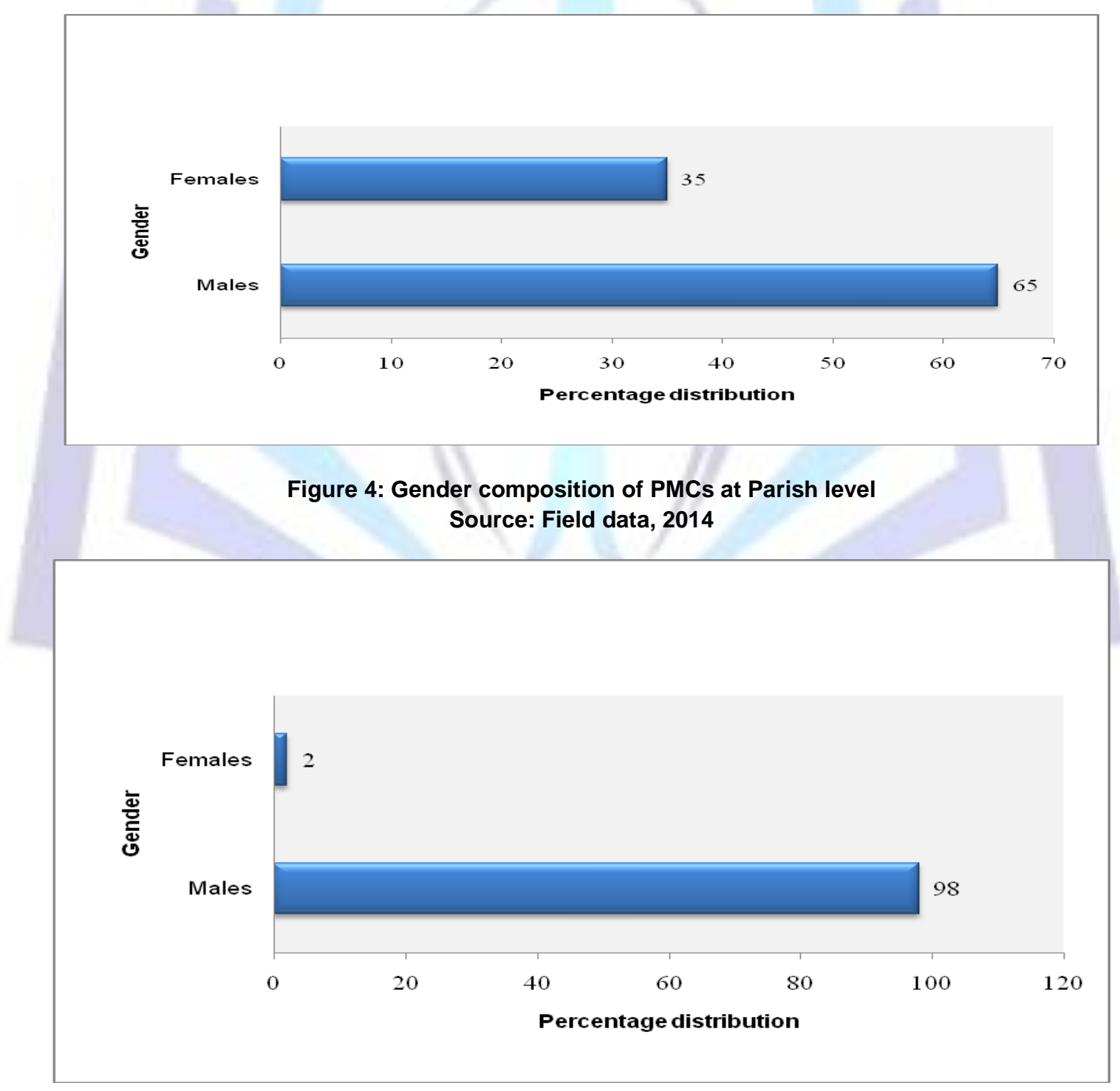

Figure 5: Gender Composition on PPC Source: Primary data, 2014 


\subsubsection{Barriers to Effective Involvement and Participation in Revenue Sharing}

Table 3 illustrates factors that limit local people's participation in revenue sharing programmes. It indicates that majority $150(26.5 \%)$ of respondents are limited to participate and get involved in Revenue Sharing activities because of crop raiding. Also, $138(24.4 \%)$ reported corruption as a barrier to participate. The least respondents (0.2\%) reported discrimination, lack of follow-up and lack of meeting allowances.

Table 3: Barriers to participation for both men and women

\begin{tabular}{|c|c|c|c|c|c|c|}
\hline \multirow[t]{2}{*}{ Barriers to participation } & \multicolumn{5}{|c|}{ Gender } & \multirow[b]{2}{*}{$\begin{array}{l}\text { Total } \\
(\%)\end{array}$} \\
\hline & $\begin{array}{l}\text { Males } \\
\text { (Freq) }\end{array}$ & $\begin{array}{l}\text { Males } \\
(\%)\end{array}$ & $\begin{array}{l}\text { Females } \\
\text { (Freq) }\end{array}$ & $\begin{array}{l}\text { Females } \\
(\%)\end{array}$ & $\begin{array}{l}\text { Total } \\
\text { (Freq) }\end{array}$ & \\
\hline Gender inequality & 20 & 5.1 & 12 & 6.8 & 32 & 5.7 \\
\hline Bad leadership & 19 & 4.9 & 6 & 3.4 & 25 & 4.4 \\
\hline Corruption & 70 & 18.0 & 68 & 38.6 & 138 & 24.4 \\
\hline Crop raiding & 120 & 30.8 & 30 & 17.0 & 150 & 26.5 \\
\hline Discrimination & 1 & 0.3 & 0 & 0.0 & 1 & 0.2 \\
\hline Limited capacity & 15 & 3.9 & 12 & 6.8 & 27 & 4.8 \\
\hline Limited information flow & 33 & 8.5 & 17 & 9.7 & 50 & 8.8 \\
\hline Poverty & 50 & 12.9 & 3 & 1.7 & 53 & 9.4 \\
\hline Lack of follow-up & 1 & 0.3 & 0 & 0.0 & 1 & 0.2 \\
\hline Lack of meeting allowances & 1 & 0.3 & 0 & 0.0 & 1 & 0.2 \\
\hline Unfairness in project distribution & 59 & 15.2 & 28 & 15.9 & 87 & 15.4 \\
\hline Total & 389 & 100 & 176 & 100 & 565 & 100 \\
\hline
\end{tabular}

Source: Primary data, 2014

\subsubsection{Leadership Groups, Institutions and Committees at Bwindi Impenetrable National Park}

The Park management of Bwindi indicated that it implements its activities using a collaborative approach where local communities are involved in natural resource management. Groups have been formed to facilitate the process of benefit sharing. This is manifested through various groups such as Resource Use Committees and the former Community Protected Institution. There are other informal park related groups operating around Bwindi that include Human Gorilla (HUGO) committees and reformed poachers committees. These groups channel local interests to UWA with the aim to increase community involvement in natural resource management. The level of success in achieving the collaborative forest management and governance remains an area of concern if a win-win situation is to be reached in governing Bwindi Impenetrable National Park resources. The capacity of these groups and committees to influence decisions was found inadequate.

The Community Protected area Institution (CPI) was analyzed as one legal former institution during FGDs in order to understand challenges in following established policy guidelines as stated by the Policy Arrangements Approach. CPI was established as a formal community link to national park management in enhancing collaborative forest management. CPI involvement in collaborative management was however analysed to be inadequate and difficult to understand (CARE, 2006). The other important channel of governance at Bwindi is the Local Government Institutions. These include; the District Councils and District Production and Environment Committees (DPECs) and Sub County Production and Environment Committees (SPECs) which should support the implementation of projects recommended and approved by the lower councils.

All CPI members reported that the nomination and selection of CPI to power was carried out differently and not in line with the UWA CPI policy of 2004. According to the policy, all CPIs were supposed to get elected from the local council hierarchical system in the capacity of secretaries of production from village level (Local Council one) to parish level (Local Council two). The difference between policy and practice was attributed to the limited knowledge of CPIs on their selection criteria. Respondents revealed that some CPIs were initially parish councilors; LCII committee members and former Park Management and Advisory Committee (PMAC).

Furthermore, the selection was different in different parishes. Most CPIs in Ikumba Sub County were selected from the Sub County councils, whereas some members in Kayonza Sub County were former members of PMAC but others were members of Local Council 11. On the other hand, CPIs in Kanungu town council and Rutenga Sub County were selected from the existing local council system as validated in Box 2. 


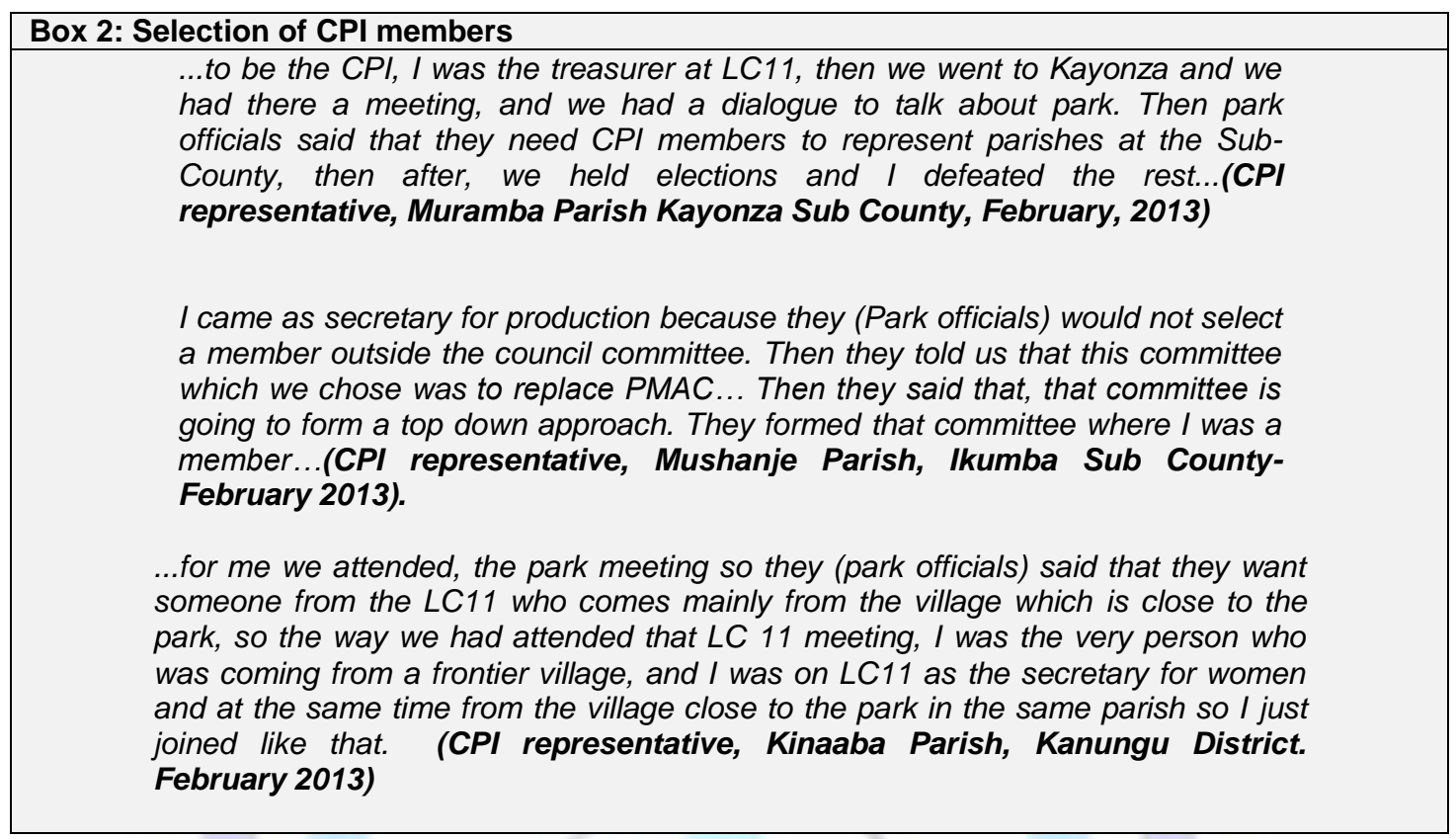

Experience with CPI members illustrates variations of which community institutions are constituted. For instance, the policy guidelines of UWA (2000) catered for secretaries of production at parish levels to choose a member that would serve as CPI. These policy guidelines were however not adhered to, the selection criteria was generally different which could explain why some local governments failed to own some CPIs in their respective Sub Counties.

\subsection{The Influence of Governance on Conservation Support}

Results reveal a relationship that exists between indicators of governance and people's support for the conservation of Bwindi. Table 4 indicates the results and values for each governance indicator.

Table 4: Relationship between governance and conservation support

\begin{tabular}{ccccc}
\hline \multicolumn{1}{c}{ Parameters } & Coefficient & Pvalue & T & Standard error \\
\hline \multicolumn{1}{c}{ Accountability } & $-0.15^{\star *}$ & 0.008 & -2.66 & 0.06 \\
$\quad$ Involvement in RS projects & $0.33^{\star * *}$ & 0.000 & 7.27 & 0.05 \\
Capacity to influence decisions & $-0.29^{* * *}$ & 0.000 & -4.20 & 0.07 \\
\hline $\begin{array}{l}* * * \\
* \text { Very highly significant at 5\% }\end{array}$ & & & & \\
\hline
\end{tabular}

Table 4 illutrates that both involvement and capacity to influence Revenue Sharing decisions highly significantly influence conservation support compared to accountability $(P$-value $=0.000)$. Accountability of revenue sharing funds was also significant and had a relationship with people's perception to support conservation $(P$-value $=0.008$, Coeff $=-0.15)$. It was only involvement in Revenue Sharing projects that had a positive relationship (Coeff $=0.33$ ) compared to accountability and capacity to influence decisions (Coeff $=.-0.15 \&-0.29$ ). This implies that as people feel involved in revenue sharing activities, see revenue sharing implementation in a transparent and accountable manner or perceive capacity to influence it, they are likely to support conservation of Bwindi. Respondents indicated that involvement was important to address their concerns and feel part of the implementation process.

\subsection{DISCUSSION OF RESULTS}

\subsection{The importance of governance as defined by local people for protected area conservation}

Local people's understanding of governance confirms the significant factors that influence both livelihood improvement and support for conservation which are presented in the results section. This is also in agreement with the previous definition of governance as, the process by which power and responsibilities are exercised and decision undertaken can have a significant influence on the conservation of protected areas (Koh, 2009). The results reveal poor implementation and governance of revenue sharing policy yet UWA has guidelines that would enable a trade-off. There is limited involvement and participation, limited information flow, limited capacity of local people to influence decisions, limited 
accountability and transparency in the management of revenue and poor composition of leadership committees and community institutions. Monitoring and feedback systems that would put local communities at the forefront of decision making processes are also not clearly in place. The top-bottom approach that is currently used is not relevant for inclusive development because it does not enable sound choices by local people that would make them own projects that are put in place. As noted, one key factor to balancing the tradeoffs of successful programmes lies in the creation of inclusive, adaptive, and sustainable governance structures that build partnerships, empower people, foster dialogue, and emphasise the use of the best science available (Koh, 2009; Scherl et al., 2004). This is true given the fact that people ought to be put at the centre of project implementation processes if they are to succeed.

The current wildlife law and policy recognizes the significance of sharing benefits from conservation with local communities through involvement (UWA, 2000a). The importance of maintaining good relationships with local communities results into long-term conservation (CARE, 2006). Management activities for Bwindi Impenetrable National Park have brought together local government, national government, and international community interests that sometimes are not in harmony with local community aspirations yet affect the outcomes of resource governance (Namara, 2006). The guidelines that govern revenue sharing however have gaps and are not followed during implementation of the policy. One key gap rotates on lack of adequate knowledge by the community and implementers in intepreting guidelines and prioritisation of projects. The evaluation of these outcomes has not been adequately undertaken due to a poor monitoring and evaluation system that tends to focus on conservation and development outcomes rather than the involvement and ownership of people in decision making process.

UWA policies and plans streamline how communities neighbouring Bwindi should share part of the revenue that comes from park revenue (UWA, 2012b). From the study, the community understanding of good governance and what is actually practiced are different. The communities would want to be at the centre of project cycle and do not support top- bottom approaches. Local people would want to be part of decision making, planning and implementation processes. Results indicate that local people's part in decision making processes is likely to be curtailed if they do not directly prioritize the projects according to their needs. This is likely to affect the impact that projects will have on their livelihood improvement. It was also established from FGDs that at the community level, meetings are always conducted before funds are disbursed. The attendance of meetings by the local people remains minimal especially the Batwa and those who live closer to the park boundary. Most people lack the motivation and incentives to benefit since little attention is given to their needs during the selection of projects. Batwa people normally expect meeting allowances and because of their poverty levels, they shun away from the meetings in an attempt to look for food in Bakiga and Bafumbira farmlands. People closer to the park boundary do not attend meetings since they spend most time guarding their crops from being raided by problem animals and vermin.

The principles of good governance such as citizenry participation and involvement, information flow and awareness, accountability, leadership and increased capacity are paramount for both livelihoods of people and their support for conservation. When the local communities do not value the importance of conservation, efforts to conserve would be in vain. What is important to note is that, the strictly protectionist approach has given way to a radical change in policy that encompasses the role of local communities in conservation (Mugisha, 2002; Baker et al., 2011). Hence, the fundamental basis of fully protected areas has been questioned, and the adoption of community-based conservation (CBC) has arisen from a greater understanding of linkages between protected areas and rural development (Baker, 2004). It has been argued that the government's response to collaborative governance needs through its parastatal agency the Uganda Wildlife Authority (UWA) included laws and policies aimed at organizing and regulating access, use and management of natural resources within national parks for local people (CARE, 2006). It is important to note that, good governance is an aspect of biodiversity conservation policies and treaties and such arrangements must entail greater involvement of local people.

Major hinderances to good governance have been highlighted in the results. As indicated in Table 3 , results show that crop raiding and corruption are the most hindrances for local involvement and participation. This hampers the linkage between conservation and development needs. Crop raiding has also been cited as a limitation to people's livelihood improvement since harvests are always lost with minimal or no compensation. This can be looked at by implementers of Revenue Sharing as an entry point for funding. The policy statement in the new guidelines about addressing human wildlife conflict remains vague when it comes to implementation. This statement in the guidelines could be unpacked and contextualized. Corruption is a major challenge even in revenue sharing project distribution which also affects people's motivation to participate. This is similar to other policies in Uganda that are hampered by corruption. Respondents identified project procurement as a major area where corruption is much manifested. Sometimes projects that are decided and procured by the tenderers such as goats or sheep do not meet the desired standards. This implies that when people get limitations to participate in key decisions that affect them, decision outcomes are likely to address issues they did not prioritize. It would be vital for UWA and development partners to look at key limitations cited in this study and address them to enable proper governance practices.

\subsection{Institutionalisation of Governance at Bwindi: The Community Protected Area Institutions}

Community protected area institutions (CPIs) have been evolving since the early 1990s (Namara, 2006). To enlist community participation in the management of national parks, Community Protected Area Institutions were instituted to represent the interests of parishes bordering a protected area (Namara, 2006). The CPI was supported by the Community Protected Area Institutions Policy (UWA, 2004), which was a strategy to promote collaborative park management and increase community involvement in PA management (CARE, 2006). This institution was mandated to act as a forum for mobilizing local communities to participate in various community conservation issues and channel and voice community concerns, and provide an avenue for Protected Area Managers to seek active involvement of local communities in natural 
resource management (UWA, 2000a). This institutional arrangement has however been abolished since 2012 after the review of the guidelines. Community institutions are important as indicated in the study to influence decision making processes and link communities to park management. Such processes translate into increase capacity and ability to benefit or distribute benefits more equitably according to the needs and priorities. This has an impact on people's livelihoods and subsequently their support for conservation. The abolition of CPIs without an alternative community institution is not a good idea given the perception of local people on local government and its practices. The high rate of corruption in local governments in Uganda cannot leave them as an alternative replacement for CPIs. The other groups within the community such as stretcher groups would be good conduits for collaboration but have limited capacity. UWA will not fully engage communities without a community institution that is trusted by local people.

\subsection{Governance of RS Projects: The Procedural Dimension of Equity to Enhance Benefit Sharing}

The use of Justice and Equity framework is paramount in protected area management. Forestry and wildlife policies of Uganda identify local community involvement in protected area management as a strategy for forest and wildlife conservation. This research illustrated that successes have been achieved among the local people that reported involvement, ownership and benefit of RS projects. This study established that communities are not always put at the centre of decision making processes and implementation of revenue sharing policy. There is calculated exclusion which is likely to be influenced by those that have an influence in the communities where projects are selected. This is likely to frustrate the success of the implemented RS projects yet communities defined full involvement as being able to contribute throughout the project cycle and being able to decide. This research also illustrated that local residents who felt involved in Revenue Sharing design and implementation were most likely to report that they benefitted from Revenue Sharing and had ownership of a Revenue Sharing project. This highlights the importance of involving local communities of Bwindi in decision-making processes for them to perceive benefits from Revenue Sharing.

Capacity of the local people to influence decisions has been cited by this study as a highly significant factor influencing livelihood improvement and their support for conservation. The current practice however shows a negative relationship between these variables (Coeff $=-0.35, P$-value $=0.000, S E=0.07, \mathrm{df}=564)$. Limited capacity was classified into two aspects. The first aspect related to the inability to influence decisions on the projects that local people are to benefit from. This is mainly attributed to high illiteracy rates, poverty and lack of voice to air out their concerns. The second classification relates to limited empowerment to advocate for issues at higher levels. This related to issues like inadquate platforms for community complaints and also failure of many organisations around Bwindi to advocate for change of policy practice. This second part of capacity entails funding in case of any advocacy need and activities. For instance, it was cited by local leaders especially CPIs that they would want to advocate for policies but get hindered by funds. Capacity for local people can be built through trainings and empowerment campaigns since it determines how their livelihoods are likely to improve.

\subsection{CONCLUSIONS AND RECOMMENDATIONS}

UWA Bwindi park management has an existing mandate to implement a collaborative management approach with local communities of Kisoro, Kabale and Kanungu. Important to note here is that collaborative forest management is different from collaborative forest governance although both are important aspects for people's livelihood and conservation. The former is too institutionalized on the structural management processes whereas the latter entails day to day decision making processes that involve all players as described in the Policy Arrangements Approach and Justice and Equity Framework. The current implementation and governance of Revenue Sharing policy suffers a lot of shortfalls in enabling good governance practices. This is a hinderance for the policy to meet its initial objectives and targets yet good governance has been illustrated in this paper as an important aspect of conservation and livelihoods. The failure of collaborative forest management and governance is manifested through continued illegal activities despite Revenue Sharing implementation and also the low socioeconomic and wellbeing status around Bwindi. Local people ought to be put at the centre of all decision making, planning, implementation and monitoring and evaluation processes. This is what will improve the level of ownership of Revenue Sharing projects and Bwindi. This could be achieved through adoption of good governance principles such as meaningful involvement and participation, local capacity, leadership committee composition, accountability and transparency and proper information flow to raise awareness.

Procedural equity is an important aspect in achieving conservation objectives and this paper recommends its adoption. This dimension of equity framework assumes that benefits are shared through inclusiveness in decision making processes thus addressing people's livelihood and conservation support as an outcome. This should entail greater involvement of people right from the beginning of the projects (design phase) to the end (evaluation phase). This is what people defined as good governance. Inclusiveness for both men and women is vital to bring all players and stakeholders on board. The more people felt involved, the more they perceived benefits and support for conservation. Revising revenue sharing guidelines should also involve local people to identify critical procedural gaps that should be addressed in order to achieve policy objectives. More involvement of frontline poorer, remote local people in revenue sharing design and implementation is paramount. This would help to overcome challenges of information flow, meeting attendance and ensuring feedback sessions with local people.

It is recommended from this study that, UWA ought to strengthen its operations with community-park institutions if its work of planning, implementation and follow-up ought to be done more efficiently. The community institutions should be trusted by both the local community members and the mainstream local government especially the Sub County which is a key player in project implementation. From discussions with CPIs, stretcher groups operate in all the communities surrounding BINP and command a good level of community trust. The stretcher groups however lack the capacity and legal mandate to operate. Ways could be sought to build their capacity through organisations such as Bwindi Mgahinga Conservation Trust (BMCT) that can be used as a starting point. The overall goal of revenue sharing is to ensure strong partnership 
between protected area management, local communities and local governments leading to sustainable management of resources in and around protected areas by enabling people living adjacent to protected areas obtain financial benefits derived from the existence of these areas that contribute to improvements in their welfare and help gain their support for protected areas conservation.

\section{ACKNOWLEDGMENTS}

Our great appreciation is extended to all our respondents in the three districts of Kabale, Kanungu and Kisoro. The following organisations and individuals are acknowledged for their technical and or financial support during field works. The International Institute for Environment and Development, The Institute of Tropical Forest Conservation,Mbarara University of Science and Technology, Uganda Wildlife Authority, Birdlife International,Conservation International, Dr. Julia Baker and Assoc. Prof. Robert Bitariho. This research study was supported by VLIR-UOS via the HEFS Platform Harvest call (ZIUS2013VOA0902). I am grateful to the platform Coordinators- Prof. Pamela Mbabazi, Prof. Van geertruyden JeanPierre, Ms. Lemey Gwen, and Ms. Edith Wakida.

\section{REFERENCES}

[1] Abbot, J., D. Thomas, A. Gardner, S. Neba, and M. Khen. 2001. Understanding the links between conservation and development in the Bamenda Highlands, Cameroon. World Development, 29(7):1115-1136.

[2] Agrawal, A., and Gibson, C.C. 1999. Enchantment and Disenchantment: The role of Community in Natural Resource Conservation. World Development. Vol.27, No.4., pp 629-649, UK.

[3] Ahebwa, W., Duim, R., and Sandbrook, C. 2012. Tourism revenue sharing policy at Bwindi Impenetrable National Park, Uganda: a policy arrangements approach, Journal of Sustainable Tourism, 20:3, pp 377-394

[4] Arts, B., and van Tatenhove, J. 2000. Environmental policy arrangements: a new concept. In: H Goverde (ed.) Global and European Polity? Impacts for Organisations and Policies. Aldershot: Ashgate. pp 223-238.

[5] Arts, B., Leroy, P., and vanTatenhove, J.V. 2006. Political Modernisation and Policy Arrangements: A Framework for Understanding Environmental Policy Change, Forest and Nature Conservation Policy Group, Wageningen University, The Netherlands

[6] Aubreville, A. 1949. Climats, Forêts et Désertification de l'Afrique Tropicale. Paris, Société d'Editions Géographiques, Maritimes et Coloniales, pp 351.

[7] Baker, J. 2004. Evaluating conservation policy: integrated conservation and development at Bwindi Impenetrable National Park. Ph.D dissertation. University of Kent, Canterbury, United Kingdom.

[8] Baker, J., Milner-Gulland, E.J., and Leader-Williams, N. 2011. Park Gazettement and Integrated Conservation and Development as Factors in Community Conflict at Bwindi Impenetrable Forest, Uganda. Society for Conservation Biology.

[9] Baker, J., Bitariho, R., Gordon-Maclean, A., Kasoma, P., Roe, D., Sheil, D., Twinamatsiko., M, Tumushabe, G., van Heist, M and Weiland, M. 2013. Linking Protected Area Conservation with Poverty Alleviation in Uganda: Integrated conservation and Development at Bwindi Impenetrable National Park, Nova Science Publishers, Inc, New York.

[10] Batisse, M. 1986. Developing and Focusing the Biosphere Reserve Concept. UNESCO Nature and Resources;22 (3) $11 \mathrm{p}$

[11] Bitariho, R. 2013. Socio-Economic and Ecological Implications of Local People's Use Of Bwindi Forest In South Western Uganda. A thesis submitted to Mbarara University. Mbarara University of Science and Technology.

[12] Blomley, T., et al. 2010. Development AND Gorillas? Assessing the effectiveness of fifteen years of integrated conservation and development in south-western Uganda. Natural resources. Issue 23. International Institute of Environment and Development, London.

[13] Brook, B.W., Ellis, E.C., Perring, M.P., Mackay, A.W., and Blomqvist, L. 2013. Does the terrestrial biosphere have planetary tipping points? Trends in Ecology and Evolution.

[14] Butynski, T.M. 1984. Ecological survey of the Impenetrable (Bwindi) Forest, Uganda, and recommendations for its conservation and management, report, New York Zoological Society, New York.

[15] CARE. 2006. CARE's Work: Project Information - Development Through Conservation, Uganda. Accessed 23/8/2006, http://www.care.org/careswork/projects/UGA030.asp

[16] CARE-Uganda. 2006. Improving Resource Access Processes in Protected Areas. A Policy Brief. Kampala, Uganda Wildlife Society.

[17] Creswell, J.W. 1998. Qualitative Inquiry and Research Design. Choosing among five traditions, Sage Publications.

[18] Creswell, J.W. 2009. Research Design: Qualitative, Quantitative and Mixed Methods Approaches, Sage Publications.

[19] Creswell, J.W., and Clark, V.L.P. 2011. Designing and Conducting Mixed Methods Research, Sage Publications

[20] DeGeorges, P. A and Reilly, B.K. 2009. The Realities of Community Based Natural Resource Management and Biodiversity Conservation in Sub-Saharan Africa. Sustainability. Pretoria, South Africa. Vol 1, 734-788; doi: 10.3390/su1030734

[21] Dytham, C. 1999. Choosing and Using Statistics: A Biologist's Guide. Journal of Ecology. Vol.87, Issue 4. Pp. $x i+218$. Blackwell Science, Oxford.

[22] Fauna \& Flora International. 2013. Batwa cultural values in Bwindi Impenetrable and Mgahinga Gorilla National Parks, Uganda; A report of a cultural assessment. Fauna \& Flora International, Cambridge. p 51.

[23] Ghimire, B.K. 1994. Parks and People. Livelihood issues in National Parks Management in Thailand and Madagascar. Development and Change. Vol.25, Issue 1, Pages 195-229.

[24] Hughes, R and Flintan, F. 2001. Integrating conservation and development experience: a review and bibliography of the ICDP literature, Biodiversity and Livelihoods issue 3, IIED, London. 
[25] Koh Tommy. 2009. "A Presentation on the Principles of Good Governance". Ministry of Foreign Affairs. Thailand, Bangkok.

[26] Kolenikov, S. and Angeles, G. 2004. The Use of Discrete Data in PCA: Theory, Simulations, and Applications to Socioeconomic Indices, Working Paper of Measure/Evaluation Project, No. WP-04 85 Carolina Population Centre, University of North Carolina.

[27] Krig, D.G. 1952. Statistical Approach to some basic mine valuation problems on the Witwatersrand. Witwatersrand.

[28] Larson, P., M. Freudenberger and B. Wyckoff-Baird. 1997. Lessons learnt from the field: a review of World Wildlife Fund's experience with integrated conservation and development projects 1985-1996. World Wildlife Fund, Washington D.C., USA.

[29] McNeeley, J., and Miller, K. 1984. National Parks, Conservation and Development, the Role of Protected Areas in Sustaining Society. Washington, DC:Smith-sonian Institution Press.

[30] McNeilage, A., et al. 2006. Census of the mountain gorilla population in Bwindi Impenetrable National Park, Uganda. Oryx 40:419-427.

[31] Mugisha, A. R. 2002. Evaluation of Community-Based Conservation Approaches: Management of Protected Areas in Uganda. A published PhD thesis. University Of Florida.

[32] Namara, A., 2006. From Paternalism to real partnership with local communities? Experiences from Bwindi Impenetrable National Park (Uganda). Africa Development 31 (2):39-68

[33] Neuman, W.L. 2011. Social Research Methods: Qualitative and Quantitative Approaches, Pearson/Allyn and Bacon.

[34] Newmark, W., and Hough, J. 2000. Conserving wildlife in Africa: Integrated conservation and development projects and beyond. Bio Science, 50, 585-592.

[35] Neyman, J. 1934. On the Two Different Aspects of the Representative Method: The Method of Stratified Sampling and the Method of Purposive Selection. Journal of the Royal Statistical Society. Vol. 97, No. 4, pp. 558-625. http://www.jstor.org/stable/2342192 Accessed: 17/10/2008 18:26

[36] Nick Salafsky. 2011. Integrating development with conservation. A means to a conservation end, or a mean end to conservation? Biology Conservation. Foundations of Success, 4109 Maryland Avenue, Bethesda, MD 20816, USA

[37] Patton, M.Q. 2002. Qualitative Research and Evaluation Methods. Sage Publications.

[38] Pemunta, N. V and Mbu-Arrey, O. P. 2013. The Tragedy of the governmentality of Nature: the Case of National Parks in Cameroon. In Johnson B. Smith (ed). National Parks: Sustainable Development, Conservation Strategies and Environmental Impacts. New York: Nova Science Publishers, pp.1-56.

[39] Polit, D.F and Beck, C. 2004. Research Principles and Methods. $7^{\text {th }}$ edition. Philadelphia: Lippincott Williams \& Wilkins.

[40] Ribot, J.C., and Peluso, N.L. 2003. A Theory of Access. Institutions and Governance Program World Resources, Institute Department of Environmental Science; Policy and Management Division of Society and Environment, University of California. Rural Sociology 68(2), 2003, pp. 153-181, Rural Sociological Society

[41] Roe, D., and Elliott, J. 2010. Poverty and Biodiversity Coonservation. Earthscan, London, UK

[42] Sandbrook, C.G. 2006. Tourism, Conservation and Livelihood: A PhD thesis. Natural Resource Issues No. 23

[43] Scherl, L.M., Wilson, A., Wild, R., Blockhus, J., Franks, P., McNeely, J.A. and McShane, T.O. 2004. Can Protected Areas Contribute to Poverty Reduction? Opportunities and Limitations. IUCN, Gland, Switzerland and Cambridge, UK. viii + 60pp.

[44] Silver, C. and Lewins, A. 2014. Using Software in Qualitative Research. A step-by-Step Guide. Second Edition. Sage Publication.

[45] Simpson, M.C. 2008. Community Benefit Tourism Initiatives-A conceptual oxymoron? Progress in Tourism Management. Oxford University Centre for the Environment, Dyson Perrins Building, South Parks Road, Oxford OX1 $3 Q Y$, UK

[46] Tumusiime, D.M., and Vedeld, P. 2012. False promise or false premise? Using tourism revenue sharing to promote conservation and poverty reduction in Uganda. Conservation and Society.

[47] Tumusiime, D.M. and H. Svarstad. 2011. A local counter narrative on the conservation of mountain gorillas. Forum for Development Studies 38(3): 1-27

[48] Turyahabwe, N; Banana, A.Y. 2008. An overview of history and development of forest policy and legislation in Uganda. Commonwealth Forestry Association, International Forestry Review, Vol.10, No. 4, pp. 641-656(16)

[49] Twinamatsiko, M., and Muchunguzi, C. 2012. The rights of minorities amidst development policy interventions. $A$ case of Basongora in South Western Uganda. Lambert Academic Publishers, Germany.

[50] Twinamatsiko,M., Baker, J., Harrison, M.,Shirkhorshidi, M.,Bitariho, R.,Weiland, M., Asuma, S., Milner-Gulland, E.J.,Franks, P., and Roe, D. 2014. Linking Conservation, Equity and Poverty Alleviation. Understanding the Profiles and Motivations of Resource Users and Local Perceptions of Governance at Bwindi Impenetrable National Park. Uganda, IIED, London.

[51] UBOS (Uganda Bureau of Statistics). 2010. Population and livelihoods report 2010. Kampala

[52] United Nations. 2003. World Economic Situation and Prospects 2003 (Sales No. E.03.II.C.2), New York, UN

[53] UNESCO. 2005. World Heritage List. United Nations Educational, Scientific and Cultural Organisation. Accessed 5/1/2006, http://whc.unesco.org/pg.cfm?cid=31\&id_site=682

[54] UWA. 1996. The Uganda Wildlife Act, Kampala, Parliament of Uganda, Kampala.

[55] UWA. 2000a. The Uganda Wildlife Law, Kampala, Ministry of Tourism, Trade and Industry.

[56] UWA. 2000b. Uganda Wildlife Authority Collaborative Management Strategy, Kampala, Uganda Wildlife Authority.

[57] UWA. 2004. Community-Protected Area Institution Policy, Kampala, Uganda Wildlife Authority. 
[58] UWA .2001. Bwindi Impenetrable National Park \& Mgahinga National Park General Management Plan July 2001 June 2011. Report. Uganda Wildlife Authority, Kampala, Uganda.

[59] UWA. 2001. Bwindi Mgahinga Conservation Area general management plan (July 2001-June 2011), Kampala: Uganda Wildlife Authority.

[60] UWA. 2012a. Guidelines for Revenue Sharing Between Wildlife Protected Areas and Adjacent Local Governments and Communities. November, 2010. Kampala, Uganda Wildlife Authority.

[61] UWA. 2012b. Revenue Sharing Policy Review. Final Draft of the Main Report, Kampala, Uganda Wildlife Authority.

[62] Van Tatenhove, J. (1999). Political modernisation and the institutionalisation of environmental policy. In: M Wissenburg, G Orhan, U Collier (eds.) European Discourses on Environmental Policy. Aldershot: Ashgate. pp 59-78.

[63] Van Tatenhove, J.P.M., Arts, B., and Leroy, P. 2000. Political modernisation and the environment: The renewal of environmental policy arrangements. Dordrecht: Kluwer Academic.

[64] Van der Zouwen, M. 2006. Dynamics in nature policy practices across the European Union. In B. Arts \& P. Leroy, (Eds.), Institutional dynamics in environmental governance (pp. 139-160). Dordrecht: Springer.

[65] Wells, M.P. and K.E. Brandon. 1993. The principles and practice of buffer zones and local participation in biodiversity conservation. Ambio, 22, 2-3: 157-162.

\section{Author' biography with Photo}

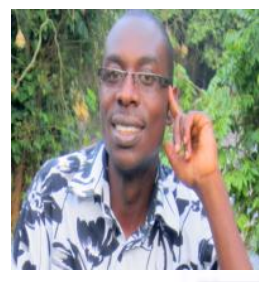

Medard Twinamatsiko has nine years of rigorous academic and research engagement. He is a $\mathrm{PhD}$ researcher in Policy Management and Natural Resource Governance at Mbarara University of Science and Technology under MUST-UTAMU collaboration and have promoters in Belgium and United Kingdom. Medard holds a first class Bachelors of Arts degree in Development Studies and a Master of Arts degree in Development Studies majoring in Development Planning and Inclusive Development obtained from Mbarara University of Science and Technology in 2009 and 2011 respectively. He also holds an Upper class Diploma in Secondary Education (Kyambogo University). His research interest is in Natural Resource Governance, Land governance, Development policy analysis and management, environmental and conservation policy planning and management. Since 2009 to the current date, Medard has had a direct interface to work with land governance platforms which include among others; Africa studies centre/Leiden University-Land governance chapter in Uganda, OSSREA land grabbing project and land competition around Uganda's protected areas such as Queen Elizabeth National Park, Lake Mburo National Park, Semliki National Park, Bwindi Impenetrable National Park and Mgahinga Gorilla National Park where he has undertaken various studies on land conflicts, natural resource competition and resource-based conflicts.

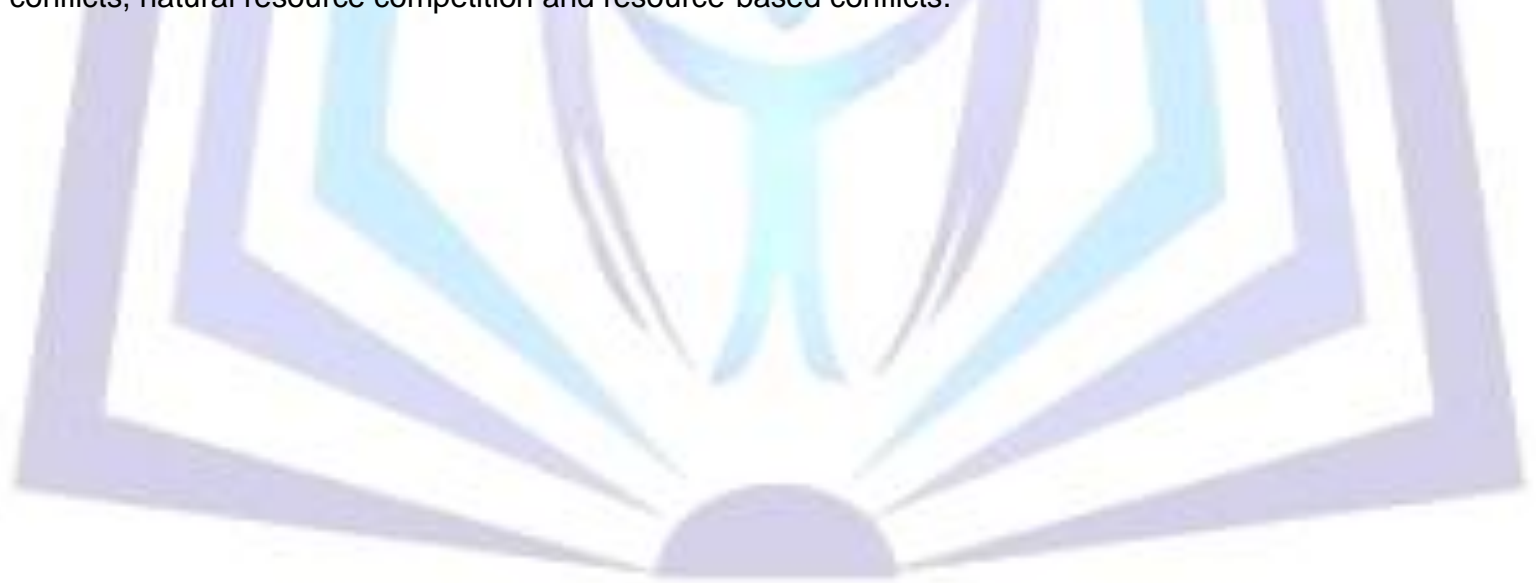

